\title{
The influence of propolis and bee pollen on chicken meat quality
}

\author{
Ivana Prakatur¹, Ivan Miškulin², Đuro Senčić1, Mirela Pavić³ ${ }^{3 *}$ Maja Miškulin², \\ Danijela Samac ${ }^{1}$, Dalida Galović ${ }^{1}$, and Matija Domaćinović ${ }^{1}$ \\ ${ }^{\prime}$ Department of Animal Production and Biotechnology, Faculty of Agrobiotechnical Sciences Osijek, Josip Juraj \\ Strossmayer University of Osijek, Osijek, Croatia \\ ${ }^{2}$ Department of Public Health, Faculty of Medicine Osijek, Josip Juraj Strossmayer University of Osijek, \\ Osijek, Croatia \\ ${ }^{3}$ Department of Anatomy, Histology and Embryology, Faculty of Veterinary Medicine, University of Zagreb, \\ Zagreb, Croatia
}

PRAKATUR, I., I. MIŠKULIN, Đ. SENČIĆ, M. PAVIĆ, M. MIŠKULIN, D. SAMAC, D. GALOVIĆ, M. DOMAĆINOVIĆ: The influence of propolis and bee pollen on chicken meat quality. Vet. arhiv 90, 617-625, 2020.

\section{ABSTRACT}

Across the world, as well as in Croatia, there is a continuous increase in the consumption of chicken meat, and attempts are being made in modern poultry production to improve its quality as much as possible by using various natural additives. The aim of this study was to determine the influence of dietary supplementation with propolis and bee pollen on the quality of chicken meat. In order to determine this effect, the carcass body weight of slaughtered chickens and carcass yield were determined, as well as the average $\mathrm{pH}_{1}$ and $\mathrm{pH}_{2}$ of chicken breast muscle, drip loss values, and skin color and chicken breast muscle color expressed as values of $\mathrm{L}^{*}$ (lightness), $\mathrm{a}^{*}$ (redness), and $\mathrm{b}^{*}$ (yellowness). The study was conducted on 200 Ross 308 chickens, divided into five groups. Throughout the study, the control group of chickens was fed with a basal diet, while the experimental groups of chickens were fed with the basal diet supplemented with propolis and bee pollen, each supplement given separately or in combination in specific proportions. At the end of the experiment ( $42^{\text {nd }}$ day), 10 chickens from each group were slaughtered for the analyses mentioned above. The carcass yield values were significantly higher $(\mathrm{P}=0.038)$ and the drip loss values were significantly lower $(\mathrm{P}=0.003)$ in the experimental groups in comparison to the control group. In addition, there was a statistically significant difference in $\mathrm{b}^{*}$ skin color $(\mathrm{P}=0.017)$ and $\mathrm{b}^{*}$ chicken breast muscle color $(\mathrm{P}<0.001)$ between the groups of chickens. The study showed that dietary supplementation with propolis and bee pollen has a significant positive effect on the quality of chicken meat.

Key words: propolis; bee pollen; broiler chickens; feeding; meat quality

\section{Introduction}

Meat is a significant nutrient in human nutrition, important for the preservation of health, and above all, important during growth and development. As

an essential part of a balanced diet, meat ensures an adequate intake of essential micronutrients and amino acids. Meat consumption is essential for the

\footnotetext{
*Corresponding author:

Mirela Pavić, DVM, PhD, Department of Anatomy, Histology and Embryology, Faculty of Veterinary Medicine, University of Zagreb, Heinzelova 55, 10000 Zagreb, Phone: +385 12390 244; E-mail: mpavic@vef.hr
} 
normal functioning of the immune system and for adequate regulatory energy metabolism processes (BIESALSKI, 2005). In the whole world, as well as in Croatia, there is a continuous increase in the consumption of chicken meat. The popularity of chicken meat and its growing consumption is the result of a number of factors, most notably its low price, the long tradition of poultry farming in almost all parts of the world, the indisputable dietary and nutritional value of chicken meat, the lack of cultural and religious barriers to consumption of this type of meat, but also the crisis in the area of food safety in the late 1990s due to bovine spongiform encephalopathy (KLARIĆ et al., 2016).

In today's modern poultry production, work is now being done on poultry feed to further improve the quality and nutritional value of meat (ZDUŃCZYK and JANKOWSKI, 2013). As a result, the use of natural additives or phytobiotics in poultry feed is particularly important, among which the use of propolis and bee pollen (GREGAČEVIĆ et al., 2014; KLARIĆ et al., 2018a) is particularly emphasized.

Propolis and bee pollen belong to a group of natural substances of animal and plant origin, with particularly pronounced antimicrobial and antioxidant effects. The bioactive components of propolis and bee pollen include flavonoids, phenolic acids and their derivatives, which are, at the same time, responsible for the bactericidal, antiviral, antifungal, analgesic, antiinflammatory, antioxidative, anticancerogenic and immunostimulatory and immunomodulatory effects of these compounds in humans and animals (BABINSKA et al., 2012; EYNG et al., 2013; KAČÁNIOVÁ et al., 2013; KLARIĆ et al., 2016; KLARIĆ et al., 2018b; KLARIĆ et al., 2018c).

So far, a limited number of studies have been carried out to investigate the influence of propolis and bee pollen on the quality of chicken meat, and the results of these studies are controversial. While ŠULCEROVA et al. (2011) concluded that feeding with a mixture of bee pollen and propolis showed little effect on the characteristics of chicken meat, HASHMI et al. (2012) showed that a small amount of added bee pollen (up to $5 \mathrm{~g} / \mathrm{kg}$ of feed mixture) had a positive effect on the most economically valuable parts of chicken meat (drumsticks, breast) by increasing the mass of these parts. In addition, HAŠČÍK et al. (2012) showed that there was a statistically significant difference in the $\mathrm{pH}$ of the chicken breasts from the experimental group in comparison to the control group of chickens.

The aim of this study was to determine the influence of dietary supplementation with propolis and bee pollen on the quality of chicken meat.

\section{Materials and methods}

Animals, diet, experimental design. The study was conducted on a total of 200 Ross 308 hybrid chickens, divided into 5 groups (40 chickens in each group, with equally distributed sexes): one control group (K) and four experimental groups (P1, P2, P3, P4). All the chickens were housed on wooden sawdust under the same conditions throughout the experimental period (42 days) according to the manufacturer's recommendations for Ross 308 hybrids (AVIAGEN, 2014). From day 1 to 21 of the study, the chickens were fed with a starter mixture. From day 22 to 42 of the study, the chickens were fed with a finisher mixture. During the whole study, feed and water were offered $a d$ libitum. Throughout the study, the control group (K) was fed a basal diet without additives, while the experimental groups (P1, P2, P3, and P4) were fed the same diet, supplemented with propolis and/ or bee pollen (each additive given separately or in combination at a certain ratio) (Table 1).

Table 1. Feeding protocol for groups

\begin{tabular}{|l|c|c|c|}
\hline \multirow{2}{*}{ Group } & \multicolumn{2}{|c|}{$\begin{array}{c}\text { No. of chickens at the } \\
\text { beginning of the study }\end{array}$} & \multirow{2}{*}{} \\
\cline { 2 - 3 } & Male & Female & Feeding protocol \\
\hline K & 20 & 20 & feed mixture \\
\hline P1 & 20 & 20 & $\begin{array}{c}\text { feed mixture } \\
\text { propolis } 0.25 \mathrm{~g} / \mathrm{kg} \\
\text { bee pollen } 20 \mathrm{~g} / \mathrm{kg}\end{array}$ \\
\hline P2 & 20 & 20 & $\begin{array}{c}\text { feed mixture }+ \\
\text { propolis } 0.5 \mathrm{~g} / \mathrm{kg}\end{array}$ \\
\hline P3 & 20 & 20 & $\begin{array}{c}\text { feed mixture }+ \\
\text { propolis } 1.0 \mathrm{~g} / \mathrm{kg}\end{array}$ \\
\hline P4 & 20 & 20 & $\begin{array}{c}\text { feed mixture }+ \text { bee } \\
\text { pollen } 20 \mathrm{~g} / \mathrm{kg}\end{array}$ \\
\hline
\end{tabular}


The experimental protocol was approved by the Committee for Animal Welfare of the Faculty of Agrobiotechnical Sciences, Osijek, of the Josip Juraj Strossmayer University of Osijek (Approval code: 602-04/18-01/01; 2158-94-02-18-01). Addition of propolis and bee pollen to the feed mixture was performed using a vertical mixer (Briketstroj Ltd., Valpovo, Croatia). The composition and calculated analyses of feed mixtures used in the chickens feeding are shown in Table 2.

Table 2. The composition and calculated analysis of the feed mixture

\begin{tabular}{|l|c|c|}
\hline & Starter & Finisher \\
\cline { 2 - 3 } & $1-21$ day & $22-42$ day \\
\hline Fodders, \% & 45.00 & 46.10 \\
\hline Flour middling & 2.80 & 3.00 \\
\hline Dehydrated alfalfa & 2.80 & 4.00 \\
\hline Soybean meal & 20.20 & 10.00 \\
\hline Sunflower meal & 4.00 & 4.00 \\
\hline Yeast & 4.00 & 3.00 \\
\hline Full fat soybean & 12.40 & 20.00 \\
\hline Vegetable oil & 3.70 & 5.00 \\
\hline $\begin{array}{l}\text { Monocalcium phos- } \\
\text { phate }\end{array}$ & 1.20 & 1.20 \\
\hline Limestone & 1.60 & 1.40 \\
\hline Salt & 0.30 & 0.30 \\
\hline Premix* & 1.00 & 1.00 \\
\hline Pigozen 801 & 1.00 & 1.00 \\
\hline Total & 100.00 & 100.00 \\
\hline Calculated analysis & & \\
\hline Crude protein, \% & 21.02 & 19.15 \\
\hline Crude fat, \% & 8.36 & 10.96 \\
\hline Crude fiber, \% & 4.96 & 5.05 \\
\hline Lysine, \% & 1.11 & 0.96 \\
\hline Methionine, \% & 0.66 & 0.61 \\
\hline Tryptophan, \% & 0.26 & 0.23 \\
\hline Calcium, \% & 1.04 & 0.98 \\
\hline Phosphorous, \% & 0.70 & 0.67 \\
\hline ME, MJ/kg & 12.30 & 13.10 \\
\hline & & \\
\hline
\end{tabular}

* Each $1 \mathrm{~kg}$ of premix contained: Vitamin A $1200000 \mathrm{IU}$; Vitamin $D_{3} 200000$ IU; Vitamin E 3000 mg; Vitamin $\mathrm{K}_{3} 250$ mg; Vitamin $B_{1} 150 \mathrm{mg}$; Vitamin $\mathrm{B}_{2} 600 \mathrm{mg}$; Vitamin $\mathrm{B}_{6} 200$ mg; Vitamin $B_{12} 1 \mathrm{mg}$; Folic acid $50 \mathrm{mg}$; Niacin $4400 \mathrm{mg}$; Ca Panthothenate $1500 \mathrm{mg}$; Biotin $10 \mathrm{mg}$; Choline chloride 50000 mg; Iron 5000 mg; Copper 700 mg; Manganese 8000 mg; Zinc $5000 \mathrm{mg}$; Iodine $75 \mathrm{mg}$; Cobalt $20 \mathrm{mg}$; Magnesium $750 \mathrm{mg}$; Selenium 15 mg; Antioxidant BHT 10000 mg; Methionine 100000 mg; Herbal carrier 1000 g.

Sample collection and measurements. On day 42, after 10-hour feed withdrawal, 10 chickens from each group were slaughtered by cervical dislocation and exsanguinated for 2 minutes. The carcasses were then manually de-feathered and eviscerated. Immediately after slaughtering and de-feathering, and without cooling, the carcasses were processed. The chicken carcasses were processed according to the principle "Prepared for barbecue" (Regulation European Commission No. 543/2008).

Carcass body weight was measured using an Avery Berkel FX 220 electronic scale (Avery Berkel, Smethwick, UK). The carcass yield was calculated as the difference between the live weight (g) and carcass body weight (g) and expressed as a percentage of the live weight.

The technological characteristics of the chicken meat quality were described by analyzing the average $\mathrm{pH}_{1}$ and $\mathrm{pH}_{2}$ of the breast muscle, drip loss values, and the skin and breast muscle color, expressed as L* (lightness), a* (redness), and b* (yellowness).

Chicken breast muscle $\mathrm{pH}$ values were measured in the internal section of the pectoral major muscle. The $\mathrm{pH}_{1}$ value was determined 45 minutes post mortem and the $\mathrm{pH}_{2}$ value was determined 24 hours post mortem by a contact $\mathrm{pH}$ meter (MP120-B, Mettler Toledo, Giessen, Germany).

In order to measure the release of water from the chicken breast muscle, the drip loss method according to KAUFFMAN (1992) was used. The chicken breast muscle sample $(3 \mathrm{~cm}$ in length and $2 \mathrm{~cm}$ in diameter) was taken from the thickest part of the breast muscle. The sample was deposited in a PVC bag and hung in a refrigerator at $+4^{\circ} \mathrm{C}$ for 24 hours. The samples were weighed before and after hanging (after 24 hours). Drip loss was calculated 
as the difference in weight and expressed as a percentage according to the following equation:

$$
\operatorname{DL}(\%)=(\mathrm{m} 1(\mathrm{~g})-\mathrm{m} 2(\mathrm{~g})) /(\mathrm{m} 1(\mathrm{~g})) \times 100
$$

where DL is drip loss [\%], $\mathrm{m} 1$ is mass before hanging, and $\mathrm{m} 2$ is mass after hanging.

The color of the chicken skin was determined on a skin section within 45 minutes post mortem, and the color of the breast muscle was determined on a cooled section of muscle after 24 hours of cooling at $4{ }^{\circ} \mathrm{C}$ using a Minolta Chroma Meter CR410 (Minolta Camera Co. Ltd., Osaka, Japan). The device was calibrated using a standard white plate (Reference No. 21633047, C Y $=94.3, \mathrm{x}=0.3135$ and $\mathrm{y}=0.3197$; $\mathrm{D} Y=94.3, \mathrm{x}=0.3160, \mathrm{y}=0.3232$ ). Before the measurement, a fresh vertical incision was made in the middle of the breast muscle. The sample was left for 10 minutes at room temperature to "stabilize" the color, after which the color of the muscle was read by the Chroma meter.

\section{Results}

The average values of carcass body weight and carcass yield in groups are shown in Table 3. It was found that there was no statistically significant difference in the carcass body weight $(\mathrm{P}=0.609)$ between the groups, while statistically significant differences were observed in carcass yield $(\mathrm{P}=$ 0.038 ) between the experimental groups.
The color of chicken skin and the color of chicken meat were expressed as CIE-L*a*b* (Commission Internationale de l'Eclairage, 1976) i.e. values of L* (lightness), a* (redness), and b* (yellowness).

Statistical analysis. The statistical analysis was carried out using statistical package Statistica for Windows 2010 (version 10.0, Stat Soft Inc., Tulsa, OK). Normality of data distribution was tested with the Shapiro-Wilkinson test. The numerical variables were described as mean \pm standard deviation (SD). ANOVA was used for comparison of the numerical variables between the groups. For all statistical analyses, two-sided P-values of 0.05 and below were considered significant. Different lowercase letters assigned to individual values in the tables, at the level of statistical significance of $\mathrm{P}<0.05$, indicate a statistically significant difference, while the same lowercase letters assigned to some values in the tables indicate the absence of statistically significant differences.

The P4 group had the lowest, whereas the P1 and $\mathrm{P} 2$ groups had the highest carcass yield. No statistically significant differences were found in the average $\mathrm{pH}_{1}(\mathrm{P}=0.567)$ and average $\mathrm{pH}_{2}$ values of the bresast muscle $(\mathrm{P}=0.153)$ between groups (table not shown).

Table 3. Estimated average \pm SD of carcass body weight (g) and carcass yield (\%) according to the groups

\begin{tabular}{|l|c|c|c|c|c|c|}
\hline \multirow{2}{*}{ Parameters } & \multicolumn{5}{|c|}{ Groups } & \multirow{2}{*}{ P-value } \\
\cline { 2 - 7 } & $\mathrm{K}$ & $\mathrm{P} 1$ & $\mathrm{P} 2$ & $\mathrm{P} 3$ & P4 & P-vas \\
\hline $\begin{array}{l}\text { Carcass body } \\
\text { weight }\end{array}$ & $1566.60 \pm 189.94$ & $1602.00 \pm 173.10$ & $1633.90 \pm 85.30$ & $1569.20 \pm 46.57$ & $1642.70 \pm 127.92$ & 0.609 \\
\hline Carcass yield & $76.50^{\mathrm{ab}} \pm 1.82$ & $77.90^{\mathrm{a}} \pm 1.94$ & $77.59^{\mathrm{a}} \pm 2.42$ & $76.46^{\mathrm{ab}} \pm 2.16$ & $75.14^{\mathrm{b}} \pm 1.96$ & 0.038 \\
\hline
\end{tabular}

Means within rows without common superscripts differ significantly by ANOVA (a,b $\mathrm{P}<0.05)$.

Table 4. Estimated average \pm SD of drip loss (\%) values according to the groups

\begin{tabular}{|l|c|c|c|c|c|c|}
\hline \multirow{2}{*}{ Parameters } & \multicolumn{5}{|c|}{ Groups } & \multirow{2}{*}{ P-value } \\
\cline { 2 - 6 } & $\mathrm{K}$ & $\mathrm{P} 1$ & $\mathrm{P} 2$ & $\mathrm{P} 3$ & $\mathrm{P} 4$ & 0.003 \\
\hline $\begin{array}{l}\text { Drip loss } \\
\text { values }\end{array}$ & $3.90^{\mathrm{a}} \pm 0.39$ & $3.69^{\mathrm{ac}} \pm 0.39$ & $3.10^{\mathrm{b}} \pm 0.53$ & $3.45^{\mathrm{bc}} \pm 0.37$ & $3.29^{\mathrm{bc}} \pm 0.58$ & 0.03 \\
\hline
\end{tabular}

Means within rows without common superscripts differ significantly by ANOVA $(\mathrm{a}, \mathrm{b}, \mathrm{c} \mathrm{P}<0.05)$. 
Table 5. Estimated average $\pm \mathrm{SD}$ of color values of chicken skin expressed as CIE-L*a*b* according to the groups

\begin{tabular}{|l|c|c|c|c|c|c|}
\hline \multirow{2}{*}{ Parameters } & \multicolumn{5}{|c|}{ Groups } & \multirow{2}{*}{ P-value } \\
\cline { 2 - 8 } & $\mathrm{K}$ & $\mathrm{P} 1$ & $\mathrm{P} 2$ & $\mathrm{P} 3$ & P4 & P-vic \\
\hline $\mathrm{L}^{*}$ & $75.94 \pm 2.75$ & $75.71 \pm 2.53$ & $74.87 \pm 3.03$ & $74.33 \pm 3.50$ & $74.84 \pm 3.10$ & 0.739 \\
\hline $\mathrm{a}^{*}$ & $5.36 \pm 0.65$ & $5.13 \pm 0.92$ & $5.60 \pm 2.15$ & $4.47 \pm 0.96$ & $4.60 \pm 0.69$ & 0.190 \\
\hline $\mathrm{b}^{*}$ & $22.47^{\mathrm{ac}} \pm 4.36$ & $18.36^{\mathrm{b}} \pm 3.28$ & $19.30^{\mathrm{bc}} \pm 4.11$ & $21.84^{\mathrm{ac}} \pm 4.00$ & $23.33^{\mathrm{a}} \pm 2.21$ & 0.017 \\
\hline
\end{tabular}

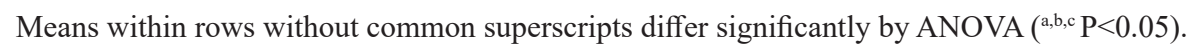

Table 6. Estimated average $\pm \mathrm{SD}$ of chicken breast muscle expressed as CIE-L*a*b* according to the groups

\begin{tabular}{|l|c|c|c|c|c|c|}
\hline \multirow{2}{*}{} & \multicolumn{7}{|c|}{ Groups } & \multirow{2}{*}{ P-value } \\
\cline { 2 - 7 } Parameters & $\mathrm{K}$ & $\mathrm{P} 1$ & $\mathrm{P} 2$ & $\mathrm{P} 3$ & $\mathrm{P} 4$ & 0.482 \\
\hline $\mathrm{L}^{*}$ & $63.13 \pm 2.62$ & $62.39 \pm 1.85$ & $62.48 \pm 2.34$ & $63.69 \pm 2.03$ & $61.90 \pm 2.76$ & 0.319 \\
\hline $\mathrm{a}^{*}$ & $12.51 \pm 1.49$ & $12.39 \pm 1.30$ & $12.07 \pm 1.29$ & $13.03 \pm 1.32$ & $13.36 \pm 1.90$ & $<0.001$ \\
\hline $\mathrm{b}^{*}$ & $14.50^{\mathrm{ac}} \pm 1.30$ & $10.23^{\mathrm{b}} \pm 2.06$ & $13.98^{\mathrm{ac}} \pm 1.65$ & $14.78^{\mathrm{a}} \pm 1.80$ & $13.04^{\mathrm{c}} \pm 2.16$ & \\
\hline
\end{tabular}

Means within rows without common superscripts differ significantly by ANOVA (a,b,c $\mathrm{P}<0.05)$.

Statistically significant differences in the drip loss value $(\mathrm{P}=0.003)$ between the control and experimental groups were observed. The $\mathrm{K}$ group had significant higher drip loss value than the P2, P3 and P4 group (Table 4).

No statistically significant differences were observed in the average values of $\mathrm{L}^{*}(\mathrm{P}=0.739)$ and $\mathrm{a}^{*}$ skin color $(\mathrm{P}=0.190)$ between groups, whereas the values of $b^{*}$ skin color showed significant differences $(P=0.017)$ between the

\section{Discussion}

The present study has shown that the carcass body weights of all the experimental groups were higher in comparison to the control group of chickens, which is in accordance with the results of the studies by HAŠČÍK et al. (2013a) and HAŠČÍK et al. (2013b) who also showed the positive effect of propolis supplementation on carcass body weight. When analyzing carcass yields in different groups of chickens, this study has further shown that there were no significant differences in carcass yields between the control group and the experimental groups. Interestingly, there was a significant difference between P1 and P4 groups, both with added bee pollen in the same concentration, which indicates that addition of low concentrations of control and experimental groups (Table 5). Similar to the average values of skin color, no statistically significant differences were found in the values of $\mathrm{L}^{*}(\mathrm{P}=0.482)$ and $\mathrm{a}^{*}$ meat color $(\mathrm{P}=0.319)$ between groups. The values of $b^{*}$ meat color $(\mathrm{P}<0.001)$ showed statistically significant differences between the analyzed groups, with distribution patterns similar to those observed in average values of $b^{*}$ skin color (Table 6).

propolis to feed mixture may have a positive effect on carcass yield. However, it is noticeable that there was a slight decrease in the carcass yield with increasing propolis concentration in the feed mixture. The latter findings are consistent with the results of the study by HAŠČÍK et al. (2013b), who showed that supplementation of propolis in a lower quantity $(150 \mathrm{mg} / \mathrm{kg}$ of feed mixture) resulted in higher values of carcass yield, while the supplementation of a higher quantity of propolis $(450 \mathrm{mg} / \mathrm{kg}$ of feed mixture) resulted in lower values of carcass yield in comparison to the control group of chickens. The positive effects observed of propolis and/or bee pollen supplementation on carcass body weight, although not statistically 
significant, can be explained by the antimicrobial and antioxidant properties of the biologically active components of these bee products, i.e. their phenolic constituents, especially flavonoids, phenolic acids and derivatives, which have been shown to have the ability to protect the intestinal villi responsible for the absorption of nutrients (AKBARIAN et al., 2013; ŠPOLJARIĆ et al., 2013). Due to their antioxidant and antimicrobial activity that modulates the intestinal ecosystem, these phenolic constituents strongly affect the utilization of nutrients, resulting in a positive effect on chicken growth performance. The results obtained are more reliable evidence that food is the main factor that can alter histological appearance or intestinal morphology, and consequently its absorption capacity, which is ultimately reflected in the performance indicators of chickens (HAMEDI et al., 2011).

When observing all the measured chicken breast muscle $\mathrm{pH}$ values, it can be said that they indicate the good quality of the chicken meat in all groups since the $\mathrm{pH}$ values were not below 5.4 and not above 7.0 when autolysis of meat appeared (HAŠČÍK et al., 2012). The results of this study are partially consistent with the results of a similar study done by ŠULCEROVÁ et al. (2011), but are however, opposite to the results of the study done by HAŠĆÍK et al. (2012). The results of this study clearly indicate that the $\mathrm{pH}$ value drops after slaughter and therefore the meat $\mathrm{pH}_{2}$ values are lower than the $\mathrm{pH}_{1}$ values. The lowering of the chicken breast muscle $\mathrm{pH}$ values is due to the fact that glycogen from the slaughtered animals is degraded into glucose. Glucose then passes through the glycolysis process, but due to the lack of oxygen, the formation of lactic acid leads to a decrease in the muscle tissue pH (ŠULCEROVÁ et al., 2011). This drop in $\mathrm{pH}$ value helps to convert muscle to meat. The final $\mathrm{pH}$ value $\left(\mathrm{pH}_{2}\right)$ affects the myofibril structure, and consequently the ability to retain water and the color of the meat (DYUBELEA et al., 2010).

The ability of muscle proteins to attract water and to keep it inside the cells is of utmost importance for the technological quality of the meat. The $\mathrm{pH}$ value is one of the most important factors that affect the value of drip loss. Low $\mathrm{pH}$ reduces the ability of muscle proteins to bind water and also reduces the negative electrostatic rejection among protein filaments, thereby narrowing the space between the filaments and causing the myofibrils to shrink. In addition, studies have shown that the lipid peroxidase content in the muscle is also associated with the values of drip loss (WANG et al., 2011). The results of our study have shown that the addition of propolis and/or bee pollen significantly decreased the drip loss values in meat from the experimental groups compared to the control group. This finding is consistent with other studies that indicated that the addition of various additives with strong antioxidant effects, such as selenium and Ginkgo biloba leaves, led to a significant decrease in chicken meat drip loss values (PERIĆ et al., 2009; WANG et al., 2011; CAO et al., 2012). The strong antioxidative activity of propolis and bee pollen, similar to selenium and Ginkgo biloba leaves, may be the reason for the significant decrease in meat drip loss values observed in the experimental groups in this study. This explanation is further supported by the fact that the strong antioxidant activity of the leaves of Ginkgo biloba is attributed to the numerous flavonoids that it contains (CAO et al., 2012), and it has already been pointed out how the antioxidative properties of propolis and bee pollen are dominantly attributed to the antioxidative properties of their biologically active components, i.e. their phenolic constituents, especially flavonoids, phenolic acids and their derivatives (AKBARIAN et al., 2013).

The intensity of chicken skin pigmentation mainly depends on the total amount of carotenoids in food, primarily xanthophylls, and their absorption and deposition in the skin and subcutaneous fatty tissue (HU et al., 2012). Poultry cannot synthesize carotenoids, and therefore they must be taken through feed (KLARIĆ, 2014). The results of our study showed that the skin of the K group was the brightest in relation to all experimental groups, although not significantly, which may be explained by the addition of propolis and/or bee pollen to their feed mixtures. Propolis and bee pollen contain a large amount of carotenoids, which when added 
to the feed were consumed by the experimental groups. Studies have shown that, among other carotenoid pigments, zeaxanthin and canthaxanthin are found in propolis and bee pollen in considerable amounts (OWAYSS et al., 2004). This is especially important due to the fact that zeaxanthin affects the value of $b^{*}$ skin color (yellowness), while the canthaxanthin affects the value of $a^{*}$ skin color (redness) in chickens. This effect of these carotenoid pigments has been demonstrated in recent studies in the world, which have shown that adding these pigments to chicken feed mixtures significantly affects the color of the skin, in terms of increasing the degree of its yellowness or redness (MORALESLOPEZ et al., 2013; TUNIO et al., 2013). Taking all the above into consideration, from the results of our study regarding the color of the chicken skin, it can be assumed that carotenoid pigments, particularly zeaxanthin and canthaxanthin, were present in the propolis and bee pollen used in this study. It can be observed that in line with the increase in the amount of propolis added, the degree of yellowness $\left(b^{*}\right)$ also increased in the experimental groups with added propolis, resulting in the highest degree of skin yellowness in chickens in the P3 group, that had the highest amount of propolis added. The results of our study also suggest that skin pigmentation with zeaxanthin was more dominant in this study because it was shown that there was a statistically significant difference between the groups according to the degree of yellowness $\left(b^{*}\right)$. Similar results were reported by HU et al. (2012), where xanthophylls of plant origin had a very good incorporation rate in broiler chicken skin.

The results of our study have shown that the addition of propolis and/or bee pollen to chicken feed mixtures has a significant effect on the breast muscle color, as demonstrated in other similar studies (KARAOGLU et al., 2006; SALÁKOVÁ et al., 2009; ŠULCEROVÁ et al., 2011). The color of the meat is a feature that significantly determines its quality, as it is the first visual criterion for consumers to assess the appearance and attractiveness of meat. Thereby, the chicken breast muscle should be pink in color, and any deviation from this nuance is considered unacceptable to consumers (GARCIA et al., 2010; KRALIK et al., 2011). Several authors (KARAOGLU et al., 2006; SALÁKOVÁ et al., 2009) have highlighted that there is a strong correlation between the color of fresh chicken breast meat and meat $\mathrm{pH}$ value 24 hours post mortem $\left(\mathrm{pH}_{2}\right)$, where the negative correlation between the $\mathrm{pH}_{2}$ value and degree of lightness $\left(\mathrm{L}^{*}\right)$ was particularly emphasized. When the $\mathrm{pH}$ value of the meat is above the isoelectric point of myofibril proteins (which is mostly at higher $\mathrm{pH}_{2}$ values), the water molecules are tightly coupled, enabling greater light absorption in the muscle, which makes the meat darker, i.e. such meat has a lower degree of lightness (L*) (SALÁKOVÁ et al., 2009). The results of our study have also confirmed the correlation between the color of fresh chicken breast meat and the $\mathrm{pH}$ value of the meat 24 hours post mortem $\left(\mathrm{pH}_{2}\right)$. Considering this, our study showed that a higher $\mathrm{pH}_{2}$ value was connected with a lower degree of lightness $\left(\mathrm{L}^{*}\right)$ (i.e. with the darker color of the meat) and with a lower degree of redness $\left(\mathrm{a}^{*}\right)$ and yellowness $\left(\mathrm{b}^{*}\right)$, as established in the study by SALÁKOVÁ et al. (2009).

\section{Conclusion}

This study showed that propolis and/or bee pollen (separately or in a combination at a certain ratio) have a significant positive effect on the quality of chicken meat, which was especially shown by the effect on carcass yield, drip loss value, and the color of skin and meat. The results of this study indicate that propolis as a supplement has better overall influence on meat quality, since it positively affects several parameters, while bee pollen dominantly affects chicken meat color and skin color. Taking into account the extent of chicken meat consumption, and also the continuous increase in consumption of this meat worldwide, the public health significance of the results of this study is very clear because it has demonstrated that the quality of chicken meat can be successfully improved in a natural way, thereby also improving the health of consumers who consume such meat. 


\section{References}

AKBARIAN, A., A. GOLIAN, H. KERMANSHAHI, R. FARHOOSH, A. R. RAJI, S. DE SMET, J. MICHIELS (2013): Growth performance and gut health parameters of finishing broilers supplemented with plant extracts and exposed to daily increased temperature. Span. J. Agric. Res. 11, 109-119.

DOI: $10.5424 /$ sjar/2013111-3392

AVIAGEN (2014): Ross 308 Broiler: Performance Objectives; Aviagen Group: Huntsville, AL, USA, 2014.

BABINSKA, I., K. KLECZEK, J. SZAREK, W. MAKOWSKI (2012): Modulating effect of propolis and bee pollen on chicken breeding parameters and pathomorphology of liver and kidneys in the course of natural infection with Salmonella Enteritidis. Bull. Vet. Inst. Pulawy. 56, 3-8.

BIESALSKI, H. K. (2005): Meat as a component of a healthy diet - are there any risks or benefits if meat is avoided in the diet? Meat Sci. 70, 509-524.

DOI: 10.1016/j.meatsci.2004.07.017

CAO, F. L., X. H. ZHANG, W. W. YU, L. G. ZHAO, T. WANG (2012): Effect of feeding fermented Ginkgo biloba leaves on growth performance, meat quality, and lipid metabolism in broilers. Poult. Sci. 91, 1210-1221.

DOI: $10.3382 /$ ps.2011-01886

DYUBELEA, N. L., V. MUCHENJE, T. T. NKUKWANAA, M. CHIMONYOA (2010): Consumer sensory characteristics of broiler and indigenous chicken meat: A South African example. Food Qual. Prefer. 21, 815-819.

EYNG, C., A. E. MURAKAMI, R. B. PEDROSO, T. G. W. SILVEIRA, D. A. L. LOURENÇO, A. F. Q. M. GARCIA (2013): Crude propolis as an immune stimulating agent in the broiler feed during the starter phase. Semin. Cienc. Agrar. 34, 2511-2522.

GARCIA, R. G., L. W. FREITAS, A. W. DE, SCHWINGEL, R. M. FARIAS, F. R. CALDARA, A. M. A. GABRIEL, J. D. GRACIANO, C. M. KOMIYAMA, I. C. L. ALMEIDA PAZ (2010): Incidence and physical properties of PSE chicken meat in a commercial processing plant. Braz. J. Poultry Sci. 12, 233-237.

GREGAČEVIĆ, L., I. KLARIĆ, M. DOMAĆINOVIĆ, D. GALOVIĆ, M. RONTA (2014): Phytogenic additives in domestic animals' nutrition. Krmiva 56, 117-123 (in Croatian).

HAMEDI, S., M. REZAIAN, T. SHOMALI (2011): Histological changes of small intestinal mucosa of cocks due to sunflower meal single feeding. Am. J. Anim. Vet. Sci. 6, 171-175.

HASHMI, M. S., P. HAŠČIK, I. ELIMAM, J. GARLÍK, M. BOBKO, M. KAČÁNIOVÁ (2012): Effects of bee pollen on the technical and allocative efficiency of meat production of Ross 308 broiler. Int. J. Poult. Sci. 11, 689-695. DOI: 10.3923/ijps.2012.689.695
HAŠČÍK, P., J. GARLÍK, V. KŇAZOVICKÁ, M. KAČÁNIOVÁ, I. OMER, E. ELIMAM, J. POCHOP, E. BENCZOVÁ, K. VAVRIŠINOVÁ (2012): Technological properties of chickens' meat after application of propolis extract in their diet. J. Microbiol. Biotechnol. Food Sci. 1, 1295-1304.

HAŠČÍK, P., J. GARLÍK, I. O. E. ELAMIN M. KAČÁNIOVÁ, V. KŇAZOVICKÁ (2013a): The effect of the propolis extract on broiler Hubbard JV internal fat. Proceedings of the $13^{\text {th }}$ International Conference Risk Factors of Food Chain, 24-26 October, Gödöllö, Hungary, pp. 1-7.

HAŠČÍK, P., J. GARLÍK, I. O. E. ELIMAM, V. KŇAZOVICKÁ, M. KAČÁNIOVÁ, M. ŠIMKO, M. MELLEN (2013b): Meat performance of chickens Hubbard JV after application of propolis extract. J. Microbiol. Biotechnol. Food Sci. 3, 118-121.

HU, C. H., D. G. WANG, H. Y. PAN, W. B. ZHENG, A. Y. ZUO, J. X. LIU (2012): Effects of broccoli steam and leaf meal on broiler performance, skin pigmentation, antioxidant function, and meat quality. Poult. Sci. 91, 2229-2234.

DOI: $10.3382 /$ ps.2012-02142

KAČÁNIOVÁ, M., P. HAŠČÍK, H. ARPÁŠOVÁ, A. PAVELKOVÁ, J. PETROVÁ, L. HLEBA, J. POCHOP, K. ROVNÁ (2013): Enterococcus genus identification isolated from gastrointestinal tract of chickens after bees products application using MALDI TOF MS biotyper. Sci. Paper. Animal. Sci. Biotech. 46, 114-118.

KARAOGLU, M., M. I. AKSU, N. ESENBUGA, M. MACIT, H. DURDAG (2006): $\mathrm{pH}$ and colour characteristics of carcasses of broilers fed with dietary probiotics and slaughtered at different ages. Asian Australas. J. Anim. Sci. 19, 605-610.

DOI: $10.5713 /$ ajas.2006.605

KAUFFMAN, R. G., R. G. CASSENS, A. SHERER, D. L. MEEKER (1992): Variations in pork quality. NPPC Publication, Des Moines, pp. 1-8.

KLARIĆ, I. (2014): Production and health effects of propolis and bee pollen as food additives in broilers feeding. $\mathrm{PhD}$ Thesis, Faculty of Agriculture in Osijek, Josip Juraj Strossmayer University of Osijek, Osijek, Croatia (in Croatian).

KLARIĆ, I., M. DOMAĆINOVIĆ, M. PAVIĆ, I. MIŠKULIN, M. MIŠKULIN, Z. STEINER (2016): The use of propolis and bee pollen in chickens feeding - a natural way to protect the health of consumers. Hrana u zdravlju i bolesti 5, 37-43 (in Croatian).

KLARIĆ, I., M. DOMAĆINOVIĆ, V. ŠERIĆ, I. MIŠKULIN, M. PAVIĆ, K. PARADINOVIĆ (2018a): Effects of bee pollen and propolis on performance, mortality, and some haematological blood parameters in broiler chickens. Slov. Vet. Res. 55, 23-34.

DOI: $10.26873 /$ SVR-385-2018 
KLARIĆ, I., I. MIŠKULIN, V. ŠERIĆ, A. DUMIĆ, J. JONJIĆ, M. MIŠKULIN (2018b): The effects of propolis and bee pollen supplementation on biochemical blood parameters of broilers. Acta Vet-Beograd 68, 190-200.

DOI: 10.2478 /acve-2018-0017

KLARIĆ, I., M. PAVIĆ, I. MIŠKULIN, V. BLAŽIČEVIĆ, A. DUMIĆ, M. MIŠKULIN (2018c): Influence of dietary supplementation of propolis and bee pollen on liver pathology in broiler chickens. Animals 8, 54.

DOI: $10.3390 /$ ani8040054

KRALIK, G., Z. ŠKRTIĆ, Z. KRALIK, I. ĐURKIN, M. GRČEVIĆ (2011): Quality of carcasses and meat of the Cobb 500 and Hubbard classic broiler chickens (in Croatian). Krmiva 53, 179-186.

MORALES-LOPEZ, R., R. AURELI, P. JENN, M. UMAR FARUK, J. SCHIERLE, F. CISNEROS (2013): Effect of supplementation of regular or zeaxanthin-enriched marigold extracts on skin pigmentation of broilers. Proceedings of the $19^{\text {th }}$ European Symposium on Poultry Nutrition, 26-29 August, Potsdam, Germany, pp. 1-3.

OWAYSS, A. A., M. M. RADY, F. M. GADALLAH (2004): Pigmentation of some honeybee, Apis mellifera L., products. Fayoum J. Agric. Res. Dev. 18, 121-132.

PERIĆ, L., N. MILOŠEVIĆ, D. ŽIKIĆ, Z. KANAČKI, N. DŽINIĆ, L. NOLLET, P. SPRING (2009): Effect of selenium sources on performance and meat characteristics of broiler chickens. J. Appl. Poult. Res. 18, 403-409.

DOI: 10.3382/japr.2008-00017
SALÁKOVÁ, A., E. STRAKOVÁ, V. VÁLKOVÁ, H. BUCHTOVÁ, I. STEINHAUSEROVÁ (2009): Quality indicators of chicken broiler raw and cooked meat depending on their sex. Acta Vet. Brno 78, 497-504. DOI:10.2754/avb200978030497

ŠPOLJARIĆ, D., G. MRŠIĆ, M. J. PETEK, I. ŠPOLJARIĆ, Ž. CVRTILA FLECK, K. ŠPIRANEC, D. MIHELIĆ, L. KOZAČINSKI, M. POPOVIĆ (2013): Chemical evaluation of the quality of meat of broilers fed with the supplement of nature propolis. Meso 15, 408-412.

ŠULCEROVÁ, H., M. MIHOK, M. JŮZL, P. HAŠČÍK (2011): Effect of addition of pollen and propolis to feeding mixtures during the production of broiler chickens Ross 308 to the colour of thigh and breast muscle and $\mathrm{pH}$ determination. Acta Univ. Agric. et Silvic. Mendel. Brun. 59, 359-366.

DOI:10.11118/actaun201159060359

TUNIO, M. T., S. YANG, Z. CHEN, M. ZUBAIR, J. QIU, Y. ZHAO, G. CHEN, Y. CHOW, A. CHEN (2013): Effect of pigments with different origins on pigmentation and performance of broilers. Pakistan J. Zool. 45, 1715-1725.

WANG, Y. X., X. A. ZHAN, X. W. ZHANG, R. J. WU, D. YUAN (2011): Comparison of different forms of dietary selenium supplementation on growth performance, meat quality, selenium deposition, and antioxidant property in broilers. Biol. Trace Elem. Res. 143, 261-273.

DOI: $10.1007 / \mathrm{s} 12011-010-8839-2$

ZDUŃCZYK, Z., J. JANKOWSKI (2013): Poultry meat as functional food: modification of the fatty acid profile - a review. Ann. Anim. Sci. 13, 463-480.

DOI: 10.2478/aoas-2013-0039

Received: 29 November 2019

Accepted: 10 February 2020

\section{PRAKATUR, I., I. MIŠKULIN, Đ. SENČIĆ, M. PAVIĆ, M. MIŠKULIN, D. SAMAC, D. GALOVIĆ, M. DOMAĆINOVIĆ: Utjecaj propolisa i pčelinjeg peluda na kvalitetu pilećeg mesa. Vet. arhiv 90, 617-625, 2020. SAŽETAK}

U čitavom svijetu, pa tako i u Hrvatskoj, bilježi se kontinuirani porast konzumacije pilećeg mesa, čija se kvaliteta u suvremenoj peradarskoj proizvodnji nastoji što više unaprijediti prije svega primjenom različitih prirodnih dodataka. Cilj ovog istraživanja bio je utvrditi utjecaj propolisa i pčelinjeg peluda kao aditiva u hranidbi tovnih pilića na kvalitetu pilećeg mesa. U svrhu utvrđivanja spomenutog utjecaja određivana je masa klaonički obrađenih trupova pilića i randman kao i prosječne vrijednosti pH1 i pH2 prsnog mišića pilića, boja kože i mesa pilića (izražena kroz tri vrijednosti: L* za stupanj svjetloće, a* za stupanj crvenila i b* za stupanj žutila) te prosječne vrijednosti otpuštanja mesnog soka. U istraživanju je tovljeno ukupno 200 pilića Ross 308 podijeljenih u pet skupina. Tijekom cijelog tova, kontrolna skupina pilića hranjena je čistom krmnom smjesom, dok su pokusne skupine pilića hranjene krmnom smjesom uz dodatak propolisa i pčelinjeg peluda (svakog aditiva zasebno ili u njihovoj kombinaciji u određenom omjeru). Po završetku tova (nakon 42 dana) i nakon 10-satnog gladovanja, žrtvovano je po 10 pilića iz svake skupine za potrebe prethodno spomenutih analiza. Utvrđene su statistički znakovito veće vrijednosti randmana $(\mathrm{P}=0,038)$ pilića pokusnih skupina u odnosu na kontrolnu skupinu kao i statistički znakovito manje vrijednosti otpuštanja mesnog soka $(\mathrm{P}=0,003)$ mesa pilića pokusnih skupina u odnosu na kontrolnu skupinu. Uz to, postojala je statistički značajna razlika u vrijednosti $b^{*}$ boje kože $(P=0,017)$ te statistički značajna razlika u vrijednosti $b^{*}$ boje mesa $(P<0,001)$ među skupinama pilića. Ovo je istraživanje pokazalo kako propolis i pčelinji pelud imaju značajan pozitivan utjecaj na kvalitetu pilećeg mesa.

Ključne riječi: propolis; pčelinji pelud; tovni pilići; hranidba; kvaliteta mesa 
